\title{
The science against sugar, alone, is insufficient in tackling the obesity and type 2 diabetes crises - We must also overcome opposition from vested interests
}

\begin{tabular}{|c|c|}
\hline \multicolumn{2}{|c|}{$\begin{array}{l}\text { Authors: } \\
\text { Aseem Malhotra }^{1} \\
\text { Grant Schofield }^{2} \\
\text { Robert H. Lustig }^{3}\end{array}$} \\
\hline \multicolumn{2}{|c|}{$\begin{array}{l}\text { Affiliations: } \\
{ }^{1} \text { Lister Hospital, Stevenage, } \\
\text { United Kingdom }\end{array}$} \\
\hline \multicolumn{2}{|c|}{$\begin{array}{l}{ }^{2} \text { Human Potential Centre, } \\
\text { Auckland University of } \\
\text { Technology, New Zealand }\end{array}$} \\
\hline \multicolumn{2}{|c|}{$\begin{array}{l}{ }^{3} \text { Department of Pediatrics, } \\
\text { University of California, } \\
\text { United States }\end{array}$} \\
\hline \multicolumn{2}{|c|}{$\begin{array}{l}\text { Corresponding author: } \\
\text { Aseem Malhotra, } \\
\text { aseem_malhotra@ } \\
\text { hotmail.com }\end{array}$} \\
\hline \multicolumn{2}{|c|}{$\begin{array}{l}\text { Received: } 04 \text { May } 2018 \\
\text { Accepted: } 04 \text { May } 2018 \\
\text { Published: } 11 \text { May } 2018\end{array}$} \\
\hline \multicolumn{2}{|c|}{$\begin{array}{l}\text { How to cite this article: } \\
\text { Malhotra A, Schofield G, } \\
\text { Lustig RH. The science against } \\
\text { sugar, alone, is insufficient in } \\
\text { tackling the obesity and type } \\
2 \text { diabetes crises - We must } \\
\text { also overcome opposition } \\
\text { from vested interests. J. insul. } \\
\text { resist. } 2018 ; 3(1) \text {, a39. https:// } \\
\text { doi.org/10.4102/jir.v3i1.39 }\end{array}$} \\
\hline \multicolumn{2}{|c|}{$\begin{array}{l}\text { C 2018. The Authors. } \\
\text { Licensee: AOSIS. This work } \\
\text { is licensed under the } \\
\text { Creative Commons } \\
\text { Attribution License. }\end{array}$} \\
\hline \multicolumn{2}{|l|}{ Read online: } \\
\hline 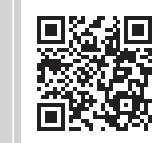 & $\begin{array}{l}\text { Scan this QR } \\
\text { code with your } \\
\text { smart phone or } \\
\text { mobile device } \\
\text { to read online. }\end{array}$ \\
\hline
\end{tabular}

\section{Introduction}

In January 2018, the Australian Medical Association called for a tax on sugary drinks to be introduced as a priority. The Association's president, Michael Gannon, likened the task ahead to taking on Big Tobacco. Here, we highlight the totality of evidence supporting a sugar tax. We also point out similarities of the tactics used by both Big Food and Big Tobacco to curb effective regulatory measures to curb obesity and diet-related metabolic disease. In fact, Big Tobacco adopted some of its methods from Big Sugar decades ago.

We should not wait decades to solve our current problems with sugar. It took 44 years from 1950, with the publication of the first study that linked smoking with lung cancer, ${ }^{1}$ for the attorney general of Mississippi to sue Big Tobacco to recoup medical costs related to the disease. $^{2}$

Big Tobacco sowed doubt that cigarettes were harmful, confused the public, persistently denied their effects, bought the loyalty of scientists and gave ammunition to political allies. ${ }^{3}$ As late as 1994, chief executives of every major tobacco firm swore under oath before US Congress that they did not believe that nicotine was addictive or that smoking caused lung cancer. $^{4}$

Now, the science demonstrating sugar's role in diet-related disease is incontrovertible, but science alone cannot curb the obesity and type 2 diabetes epidemics. Opposition from vested interests that profit from diminishing society's health must be overcome.

\section{The case against sugar}

The optimum - and, at the very least, required - amount of dietary sugar we need is zero. Dietary sucrose comprises two molecules: glucose and fructose. Although glucose is often called the 'energy of life' and all eukaryotic cells can burn it for energy, we do not need to consume it because the liver can convert amino acids and the glycerol backbone of fatty acids to glucose (gluconeogenesis). This is why we can maintain normal glucose homeostasis while fasting for weeks at a time.

Fructose, however, is unnecessary for any biochemical reaction in eukaryotic cells; there is no biological requirement and it has no nutritional value other than energy. And when consumed in excess, fructose meets the following four criteria of public health experts for regulation. ${ }^{5}$

\section{Ubiquity}

Sugar has been added to most forms of processed food for taste, bulk and preservation. Around $74 \%$ of foods in grocery stores or supermarkets contain added sugar. ${ }^{6}$ Children and adults in the United States consume a mean of 19 and 18 teaspoons daily, respectively, ${ }^{7}$ with similar estimates in the United Kingdom and Australasia. ${ }^{8}$ Despite warnings linking sugar to chronic diseases, consumption has increased on all continents in the last decade. ${ }^{9}$ The World Health Organization originally proposed a maximum of 6 teaspoons of added sugar per day, but food lobbies pressured them to adopt an upper limit of 12 teaspoons, which the US Department of Agriculture affirmed. To curb dental caries, researchers at the London School of Hygiene and Tropical Medicine suggest no more than 3\% of calories or 3 teaspoons per day. 


\section{Toxicity}

Recent prospective studies, controlled for calories, adiposity and time, show that added sugar is a cause of type 2 diabetes. ${ }^{10,11,12}$ Similarly, a recent meta-analysis showed that sugar consumption, after excluding obesity, correlated with type 2 diabetes prevalence. ${ }^{13}$

An econometric analysis of the UN Food and Agriculture Organization statistics database, which lists by food availability per person by country (2000-2010), showed that only added sugar availability predicted changes in type 2 diabetes rates. For every excess 150 calories per day, diabetes prevalence increased by $0.1 \%$, but if those 150 calories came from a can of soda, diabetes prevalence increased 11 -fold (by $1.1 \%){ }^{14}$

A recent study examined the effects of isocaloric substitution of sugar with starch in 43 children with metabolic syndrome over a 10-day period. When the per cent calories as dietary sugar were reduced from $28 \%$ to $10 \%$, keeping calories and weight constant, every aspect of metabolic health improved: diastolic $\mathrm{BP}$ reduced by $5 \mathrm{mmHg}$, triglycerides reduced by $46 \%$, low-density lipoprotein (LDL) cholesterol by $0.3 \mathrm{mmol} / \mathrm{L}$ and insulin sensitivity improved, coincident with a liver fat reduction of $22 \%$, with no changes in calories or weight. ${ }^{15,16}$

Sugar has long been known to adversely affect teeth. In the United Kingdom, the most common cause of chronic pain and hospital admissions in young children (aged 5-9 years) is tooth decay driven by sugar. ${ }^{17}$

\section{Abuse \\ Fructose directly increases consumption independent of energy need. ${ }^{18}$ Along with caffeine, it seems to be the food additive that makes 'fast food' addictive. ${ }^{19}$ Fructose and glucose have different sites of action and generate two different effects. Glucose produces satiety or fullness, while fructose does not. ${ }^{20}$ Glucose lights up the cortical executive control areas, but fructose suppresses the signal coming from those control areas. ${ }^{21}$}

High-fat milkshakes increase brain activity in sensory areas concerning 'mouthfeel', whereas high-sugar milkshakes increase limbic system activity. ${ }^{22}$ In other words, fat increases the salience of sugar, but it is the sugar that drives the reward. Although sugar does not exhibit classic withdrawal, it demonstrates what the DSM-5 qualifies as 'dependence'. ${ }^{23}$

\section{Negative impact on society}

Sugared beverages alone are estimated to kill 184000 people per year globally. ${ }^{24}$ A population reduction of added sugar consumption of just $20 \%$ could reduce obesity, type 2 diabetes, heart disease, death rates and medical expenditures within 3 years in the United States. ${ }^{25}$

Morgan Stanley modelled global economic growth rates to the year 2035 in low-sugar and high-sugar simulations. ${ }^{26}$
Population-wide sugar reduction would prevent premature death, save economies billions and improve quality of life for millions across the globe.

\section{The case against the processed food industry}

As with tobacco, policy changes that target availability, affordability or acceptability (e.g. the Mexico sugar tax) are overwhelmingly effective in curbing sugar consumption. ${ }^{27}$ But the sugar industry, their partners and political allies utilise numerous instruments to deflect culpability and derail policy change. Some involve influencing science, and some involve influencing public opinion. ${ }^{28}$

\section{Influencing science}

\section{Linking sugar to obesity rather than to diabetes}

The food industry often tries to divert the public health conversation toward obesity. ${ }^{29}$ Sugar ranks below potato chips and French fries as a cause of weight gain $^{30}$; the data correlating sugar consumption to obesity are weak, accounting for only about $10 \%$ of the observed effect. ${ }^{31}$ This is the basis of the food industry's message; if sugar is only one of many causes of obesity, it can iterate its mantra, 'a calorie is a calorie'. To them, it is about energy balance, gluttony and sloth, diet and exercise, and if you are overweight it is your fault. Yet, when weight and calories are factored out, the correlation between sugar consumption and type 2 diabetes is much stronger. ${ }^{13,14}$ Furthermore, there are countries where diabetes rates are high, yet obesity rates are low, such as India, Pakistan and China - while their sugar consumption has increased by $15 \%$ in the past 6 years alone. ${ }^{32}$ To date, the food industry refuses to engage in a discussion on the role of added sugar in chronic metabolic diseases, exclusive of obesity.

\section{Paying scientists}

The sugar industry has a long history of co-opting scientists. A team at the University of California, San Francisco, have discovered the paper trail of influence by the Sugar Research Foundation to exonerate sugar and divert attention to saturated fat as a cause of cardiovascular disease (CVD) in 1967,33 and to divert attention away from sugar as a cause of dental caries in $1971 .^{34}$

Since then, those in the sugar, high-fructose corn syrup, beverage and processed food industries have paid for scientists' complicity in marketing sugar as healthy. ${ }^{35}$ More recently, an analysis of Web of Science citations from 2008 to 2016, which searched for Coca-Cola conflicts of interest regarding funding, identified 779 articles. Subsequent comparison with Coca-Cola's own transparency website (https:/ / www.coca-colacompany.com/transparency/ourcommitment-transparency) identified 128 articles and 471 authors who were not disclosed by Coca-Cola, and 19 academic investigators who had direct email contact with the company. $^{36}$ 


\section{Obfuscating scientific research}

One would expect the totality of evidence on the detrimental effects of sugar to be reflected in systematic reviews or metaanalyses, but many publications yield inconsistent results. ${ }^{37,38,39}$

Many of these studies are funded by the food industry, which dilutes the data to obfuscate any significant effects and minimise evidence and impact (Garbage In, Garbage Out). ${ }^{40}$ Also, studies funded by industry are 7.61 times more likely to show a conclusion favourable to that industry. ${ }^{41}$

The industry's influence in distorting public health messages extends to institutions and organisations that have a responsibility to scientific integrity, such as the University of Sydney, which used 'flawed' data to claim there is an 'Australian Paradox' (http:/ / www.australianparadox.com/) (sugar intake has decreased while obesity rates have risen ${ }^{42}$ to exonerate sugar as a cause of obesity ${ }^{43,44}$ ). The veracity of those data sets and conclusions is challenged by other independent nutritionists.

\section{Co-opting public health experts}

For years, soft drink companies' public relations machinery has pushed the lack of physical activity as a cause of obesity, when there is evidence to reveal that although sedentary lifestyle contributes to chronic disease, physical activity's impact is minimal at best and you cannot outrun a bad diet. ${ }^{45}$

Beverage companies have sponsored numerous public health efforts, provided they did not address soft drinks. ${ }^{46}$ Brenda Fitzgerald, the recently disgraced director of the US Centers for Disease Control, had partnered with Coca-Cola as Georgia's public health commissioner, ${ }^{47}$ who also bankrolled the Global Energy Balance Network, a consortium of three academics, to push lack of exercise as the cause of obesity. ${ }^{48}$ Even Michelle Obama caved to food industry pressure; during the US president's second term, she shifted her focus away from the importance of a healthy diet towards promoting physical activity. ${ }^{49}$

The US Academy of Nutrition and Dietetics, British Dietetic Association (BDA) and the Dieticians' Association of Australia all receive annual contributions from the food industry. ${ }^{50}$ It is extraordinary that the BDA has also promoted Nestle Health Science on its homepage. Nestle has not only been a prominent marketer of sugary products for children, but has also been the target of a boycott by respected international organisation Baby Milk Action for contributing 'to the unnecessary death and suffering of infants around the world by aggressively marketing baby foods in breach of international marketing standards ${ }^{\prime}{ }^{51}$ These organisations are wittingly or unwittingly behaving more like front groups for the processed food industry - this must be exposed.

\section{Influencing public opinion}

\section{Personal responsibility}

Perhaps the most potent messaging of the food industry is that the public should exercise personal responsibility: 'it's your fault you're fat'.
Science journalist Gary Taubes says to use this argument is criminal, and we concur. It also flies in the face of the broad social-ecological approach of public health practice, which understands that there are multiple, hierarchical and interacting policy, environmental, social and demographic factors affecting behaviours which are well evidenced and understood.

The personal responsibility strategy was first deployed by tobacco companies in 1962 as a reason to keep on smoking. ${ }^{3}$ This ideology requires the following four prerequisites.

Knowledge: Information labelling is not easily understandable by the regular consumer buying food products in the supermarket. Many will trust and buy a product on the way it is promoted, rather than on its nutritional value. And until recently, the US Institute of Medicine, and in the United Kingdom and the rest of Europe for the past 15 years, guideline daily amounts on labels have suggested that daily consumption of up to 22 teaspoons of sugar is healthful. ${ }^{52}$

Access: Over 70\% of foods in the supermarket contain added sugar - it has become almost unavoidable. Processed sugary food and drinks have permeated workplaces, gyms and schools. We are heartened that the UK National Health Service has announced a ban on sugary drinks sold in hospitals, to start in July 2018.

Affordability: One should afford their choice, and society has to afford it too. Healthy food was twice as expensive as processed food in 2002, and its cost increased by $£ 0.17$ per pound per year over the next 10 years, compared with processed food, which increased $£ 0.07$ per pound per year. ${ }^{53}$

Non-anarchy: The medical costs of chronic metabolic disease related to sugar consumption will cause a doubling of Medicare costs in the next decade, ${ }^{54}$ bankrupting health care systems around the world, ${ }^{55,56}$ and the UK National Health Service is under an ever-tighter squeeze, resulting in lengthier waiting times. ${ }^{57}$ The argument that your actions cannot harm anyone else ignores the diet-related harm experienced by children who are especially vulnerable to poor diet at critical development stages.

\section{Weakening government oversight}

In 1972, Sugar Information, Inc. ran a public disinformation campaign to deflect criticism from its product. The US Federal Trade Commission (FTC) engaged in a damaging court battle, which shuttered their efforts. ${ }^{58}$ Yet in the late 1970s, efforts to ban junk food marketing on television led to a corporate power struggle pressuring Congress to 'declaw' the FTC, which occurred in 1984..$^{9}$ This also saw the rise of the American Legislative Exchange Council (ALEC), a 'bill mill' that writes legislation beneficial to the food industry and pays off Congressmen to introduce these bills to benefit industry. Most recently, the Trump administration plans to limit the information on junk food labels, which could act as 
pre-emption for soda taxation in the United States and possibly repeal of the soda tax in Mexico. ${ }^{60}$

\section{Trade organisations}

Numerous front groups promote food industry interests and lobby politicians in the open; for example, in the United States, the Grocery Manufacturers Association, American Beverage Association and National Restaurant Association. In the United Kingdom, the Food and Drink Federation performs similar functions. In Australia and New Zealand, the Sugar Research Advisory Service (https://www.srasanz.org/) (SRAS) is claimed to be a scientific information Service for health professionals, academics and the media, which aims to provide an evidence-based view of the role of sugars in nutrition and health, but it is fronted by academics and health professions receiving money directly from the industry.

\section{Astroturf groups}

Astroturf groups are citizens' non-profit groups that mask their sponsors to appear as though they are grassroots organisations. For instance, in the United States, the Center for Organizational Research and Education's (CORE; formerly the Center for Consumer Freedom) name is deliberately designed to divert attention away from industry connection. It claims to be 'dedicated to protect consumer choices and promoting common sense'. It is funded by fast food, meat, alcohol and tobacco industries. ${ }^{61}$ The group was originally founded in the mid-1990s, using tobacco and restaurant industry money to oppose smoking restrictions in restaurants. Its founder, Richard Berman, also founded the American Beverage Institute, which fights restrictions on alcohol use and raising the minimum wage. In a secretly recorded interview reported by The New York Times, Berman encouraged industry players to attack those that oppose industry interests and they could either 'win ugly or lose pretty'. ${ }^{62}$

Similarly, in the United Kingdom, the Institute of Economic Affairs (IEA), an organisation that describes itself to be 'the UK's original free-market think-tank', claims to be independent of any political party, group or organisation. But in 2016, Transparify - which provides ratings of financial transparency of major think tanks - gave a 'highly opaque' zero score. $^{63}$

The IEA has received undisclosed voluntary donations from a number of organisations including Big American Tobacco, Coca-Cola Great Britain and Ireland, and sugar manufacturer Tate and Lyle. ${ }^{64}$ As Transparify states ${ }^{63}$ :

The more lobbyists try to hijack the 'think tank' label in an attempt to mask their paid-for spin as research-driven advocacy, the more important it becomes for the think tank sector as a whole to fight back. The best weapon in that fight is transparency.

In July 2014, the IEA produced a report arguing that lack of physical activity was driving the obesity epidemic rather excess calories, which it claimed had actually reduced in the past three decades. ${ }^{65}$ When questioned on Channel 4 News on whether the organisation takes money from the food industry, spokesman Christopher Snowdon replied that the question was 'highly irrelevant'. Snowdon, who does not have a medical or science background, has authored many opinion pieces opposing a sugar tax for Spectator Health. On BBC Newsnight in December 2017, Snowdon suggested that organisations calling for reduced sugar, alcohol and tobacco are responsible for increasing misery in society, and also suggesting that we could not be healthier.

\section{Methods to battle vested interests}

Twenty-five of the 30-year average increase in life expectancy in the past century can be directly attributed to public health measures that were underpinned by regulation, including safe drinking water, safer working environments, seat belts in cars, smoke-free buildings and immunisations. ${ }^{66}$

The regulatory approaches that addressed the acceptability, affordability and availability of tobacco have been the most important factors driving decline in CVD mortality since 1969. A public education campaign, combined with smokefree building regulations and banning of tobacco advertising, was an important measure for reducing smoking prevalence and, in turn, reducing CVD. However, the taxing of cigarettes was responsible for the biggest impact by far. Unfortunately, the increasing prevalence of obesity and type 2 diabetes driven by poor diet, and, in particular, sugar consumption, is costing billions to national economies every year, resulting in loss of economic productivity. ${ }^{26}$

Industry has a right to use information to market its products, but it does not have a right to use disinformation to propagandise them. The public deserves to know the financial relationships between organisations and those who represent their interests. We must ask editors of respectable print and broadcast media whether it is appropriate to give a platform to an individual who uses unprofessional, defamatory and abusive language when describing respected public health advocates. Simon Chapman is a professor of public health at the University of Sydney who has been one of the most influential figures in campaigning for tobacco control in Australia. The IEA's Snowdon has described Chapman as a 'scrotum-faced headbanger' who freely promotes 'junk science' and Stan Glantz of University of California San Francisco as a 'raving lunatic', 'gobshite' and 'clueless clown' ${ }^{67}$ As Duke University professor Kelly Brownell describes, Big Food uses dirty tricks to deflect blame for their own role in exacerbating the obesity epidemic, including attacking those calling for greater regulation as peddling junk science, and calling them 'food fascists' and leaders of the 'nanny state'. ${ }^{68}$

\section{Recommendations}

We offer the following public health interventions to reduce sugar consumption, all of which are evidence-based and all of which were successful in curbing tobacco use. This suite of recommendations reflects an evidence-based, broad, socio-ecological approach to creating environments which 
help move society in the direction of food environments where sugar is no longer ubiquitous:

1. Education for the public should emphasise that there is no biological need or nutritional value of added sugar. Industry should be forced to label added and free sugars on food products in teaspoons rather than grams, which will make it easier to understand.

2. There should be a complete ban of companies associated with sugary products from sponsoring sporting events. We encourage celebrities in the entertainment industry and sporting role models (as Indian cricketer Virat Kohli and American basketballer Stephan Curry have already done) to publicly dissociate themselves from sugary product endorsement.

3. We call for a ban on loss leading in supermarkets and running end-of-aisle loss leading on sugary and junk foods and drinks.

4. Sugary drinks taxes should extend to sugary foods as well.

5. We call for a complete ban of all sugary drink advertising (including fruit juice) on TV and internet demand services.

6. We recommend the discontinuing of all governmental food subsidies, especially commodity crops such as sugar, which contribute to health detriments. These subsidies distort the market and increase the costs of non-subsidised crops, making them unaffordable for many. No industry should be provided a subsidy for hurting people.

7. Policy should prevent all dietetic organisations from accepting money or endorsing companies that market processed foods. If they do, they cannot be allowed to claim that their dietary advice is independent.

8. We recommend splitting healthy eating and physical activity as separate and independent public health goals. We strongly recommend avoiding sedentary lifestyles through promotion of physical activity to prevent chronic disease for all ages and sizes, because 'you can't outrun a bad diet'. ${ }^{49}$ However, physical (in)activity is often conflated as an alternative solution to obesity on a simple energy in-and-out equation. The evidence for this approach is weak. This approach necessarily ignores the metabolic complexity and unnecessarily pitches two independently healthy behaviours against each other on just one poor health outcome (obesity). The issue of relieving the burden of nutrition-related disease needs to improve diet, not physical activity.

Retrospective econometric analysis ${ }^{14}$ and prospective Markov modelling ${ }^{25}$ both predict that the prevalence of type 2 diabetes will start to reduce 3 years after implementing these measures. This calamity has been 40 years in the making 3 years is not too long to wait.

\section{Acknowledgements}

\section{Competing interests}

The authors declare that they have no financial or personal relationships which may have inappropriately influenced them in writing this article.

\section{Authors' contributions}

A.M. conceived the idea for the article and wrote the initial draft with further additions and edits from R.H.L. and G.S.

\section{References}

1. Doll R, Bradford Hill A. Smoking and carcinoma of the lung. $\mathrm{Br}$ Med J. 1950;2(4682):739-748. https://doi.org/10.1136/bmj.2.4682.739

2. leyoub RP, Eisenberg T. State attorney general actions, the tobacco litigation, and the doctrine of Parens Patriae. Tul L Rev. 2000;74(5\&6):1859-1860.

3. Proctor RN. Golden holocaust: Origins of the cigarette catastrophe and the case for abolition. Berkeley, CA: University of California Press; 2011.

4. Tobacco Free Florida. 1994 - Tobacco company CEO's testify before Congress [homepage on the Internet]. 1994 [cited 2018 Apr]. Available from: https://www. youtube.com/watch?v=e_ZDQKq2F08

5. Lustig $R H$, Schmidt $L A$, Brindis $C D$. The toxic truth about sugar. Nature. 2012;487(7383):27-29. https://doi.org/10.1038/482027a

6. Ng SW, Slining MM, Popkin BM. Use of caloric and noncaloric sweeteners in US consumer packaged foods, 2005-2009. J Acad Nutr Diet. 2012;112(11):1828-1834. https://doi.org/10.1016/j.jand.2012.07.009

7. Powell ES, Smith-Taillie LP, Popkin BM. Added sugars intake across the distribution of US children and adult consumers: 1977-2012. J Acad Nutr Diet. 2016;116(10): 1543-1550. https://doi.org/10.1016/j.jand.2016.06.003

8. Ministry of Health, New Zealand. Annual update of key results 2014/15: New Zeland Health Survey [homepage on the Internet]. 2015 [cited 2018 Apr]. Available from:
https://www.health.govt.nz/publication/annual-update-key-results-2014-15-newhttps://www.health.go
zealand-health-survey

9. Popkin BM, Hawkes C. Sweetening of the global diet, particularly beverages: Patterns, trends, and policy responses. Lancet Diab Endccrinol. 2016;4(2):174-186. https://doi.org/10.1016/\$2213-8587(15)00419-2

10. Consortium I. Consumption of sweet beverages and type 2 diabetes incidence in European adults: Results from EPIC-InterAct. Diabetologia. 2013;56(7):1520-1530. https://doi.org/10.1007/s00125-013-2899-8

11. Imamura $F, O^{\prime}$ Connor $L$, Ye $Z$, et al. Consumption of sugar sweetened beverages, artificially sweetened beverages, and fruit juice and incidence of type 2 diabetes: Systematic review, meta-analysis, and estimation of population attributable fraction. BMJ. 2015;351:h3576. https://doi.org/10.1136/bmj.h3576

12. Rodriguez LA, Madsen KA, Cotterman C, Lustig RH. Added sugar intake and metabolic syndrome in US adolescents: Cross-sectional analysis of NHANES 2005-2012. Public Health Nutr. 2016;19(13):2424-2434. https://doi.org/10.1017/S1368980016000057

13. Deshpande G, Mapanga RF, Essop MF. Frequent sugar-sweetened beverage consumption and the onset of cardiometabolic diseases: Cause for concern? J Endocr Soc. 2017;1(11):1372-1385. https://doi.org/10.1210/js.2017-00262

14. Basu S, Yoffe P, Hills N, Lustig RH. The relationship of sugar to population-level diabetes prevalence: An econometric analysis of repeated cross-sectional data. PLoS One. 2013;8(2):e57873. https://doi.org/10.1371/journal.pone.0057873

15. Lustig RH, Mulligan K, Noworolski SM, et al. Isocaloric fructose restriction and metabolic improvement in children with obesity and metabolic syndrome. Obesity. 2016;24(2):453-460. https://doi.org/10.1002/oby.21371

16. Schwarz JM, Noworolski SM, Erkin-Cakmak A, et al. Impact of dietary fructose restriction on liver fat, de novo lipogenesis, and insulin kinetics in children with obesity. Gastroenterology. 2017;153(3):743-752. https://doi.org/10.1053/j.gastro. 2017.05.043

17. Sheiham AS, James WPT. A reappraisal of the quantitative relationship between sugar intake and dental caries: The need for new criteria for developing goals for sugar intake. BMC Public Health. 2014;14:863. https://doi.org/10.1186/14712458-14-863

18. Lindqvist A, Baelemans A, Erlanson-Albertsson C. Effects of sucrose, glucose and fructose on peripheral and central appetite signals. Regul Pept. 2008;150(1-3):26-32. https://doi.org/10.1016/j.regpep.2008.06.008

19. Garber AK, Lustig RH. Is fast food addictive? Curr Drug Abuse Rev. 2011;4(3):146162. https://doi.org/10.2174/1874473711104030146

20. Wölnerhanssen BK, Meyer-Gerspach AC, Schmidt A, et al. Dissociable behavioral, physiological and neural effects of acute glucose and fructose ingestion: A pilot physiological and neural effects of acute glucose and fructose ingestion: A pilot
study. PLOS One. 2015;10(6):e0130280. https://doi.org/10.1371/journal.pone. study. PL 0130280

21. Purnell JQ, Klopfenstein BA, Stevens AA, et al. Brain functional magnetic resonance imaging response to glucose and fructose infusions in humans. Diab Obes Metab. 2011;13(3):229-234. https://doi.org/10.1111/j.1463-1326.2010.01340.x

22. Stice $\mathrm{E}$, Burger $\mathrm{KS}$, Yokum S. Relative ability of fat and sugar tastes to activate reward, gustatory, and somatosensory regions. Am J Clin Nutr. 2013;98(6):1377-1384. https://doi.org/10.3945/ajcn.113.069443

23. Lustig RH. Food addiction? Or food and addiction? A scientific and legal analysis PLoS Biol. In press 2018.

24. Singh GM, Micha R, Khatibzadeh S, et al. Estimated global, regional, and national disease burdens related to sugar-sweetened beverage consumption in 2010. Circulation. 2015;132(8):639-666. https://doi.org/10.1161/CIRCULATIONAHA. 114.010636

25. Vreman RA, Goodell AJ, Rodriguez LA, et al. Health and economic benefits of reducing sugar intake in the United States, including effects via non-alcoholic fatty liver disease: A microsimulation model. BMJ Open. 2017;7(8):e103543. https:// doi.org/10.1136/bmjopen-2016-013543 
26. Morgan Stanley Research. Sustainable economics: The bittersweet aftertaste of sugar [homepage on the internet]. 2015 [cited 2018 Apr]. Available from: http:// sugar [homepage on the internet]. 2015 [cited $2018 \mathrm{Apr}$ ]. Available from: http:// static.latribune.fr/46307

27. Colchero MA, Rivera-Dommarco J, Popkin BM, Ng SW. In Mexico, evidence of sustained consumer response two years after implementing a sugar-sweetened beverage tax. Health Aff. 2017;36(3):564-571. https://doi.org/10.1377/hlthaff. 2016.1231

28. Taubes G. The case against sugar. New York: Knopf; 2016.

29. Van Buul VJ, Tappy L, Brouns FJ. Misconceptions about fructose-containing sugars and their role in the obesity epidemic. Nutr Res Rev. 2014;27(1):119-130. https:// doi.org/10.1017/S0954422414000067

30. Mozaffarian D, Hao T, Rimm EB, Willett WC, Hu FB. Changes in diet and lifestyle and long-term weight gain in women and men. N Engl J Med. 2011;364(25):23922404. https://doi.org/10.1056/NEJMoa1014296

31. Te Morenga L, Mallard S, Mann J. Dietary sugars and body weight: Systematic review and meta-analyses of randomised controlled trials and cohort studies. BMJ. 2013;346:e7492. https://doi.org/10.1136/bmj.e7492

32. Gulati S, Misra A. Sugar intake, obesity, and diabetes in India. Nutrients. 2014;6(12): 5955-5974. https://doi.org/10.3390/nu6125955

33. Kearns $C E$, Schmidt LA, Glantz SA. Sugar industry and coronary heart disease research: A historical analysis of internal industry documents. JAMA Intern Med.

2016;176(11):1680-1685. htps://doi.org/10.1001/jamainternmed.2016.5394

34. Kearns CR, Glantz SA, Schmidt LA. Sugar industry influence on the scientific agend historical analysis of internal documents. PLoS Med. 2015;12(3):e1001798. https:// doi.org/10.1371/journal.pmed.1001798

35. Stuckler D, Ruskin G, McKee M. Complexity and conflicts of interest statements: A case-study of emails exchanged between Coca-Cola and the principal investigator of the International Study of Childhood Obesity, Lifestyle and the Environment (ISCOLE). J Public Health Policy. 2018;39(1):49-56. https://doi.org/10.1057/ s41271-017-0095-7

36. Serôdio PM, McKee M, Stuckler D. Coca-Cola - A model of transparency in research partnerships? A network analysis of CocaCola's research funding (2008-2016). Public Health Nutr. 2018;21:1-4. https://doi.org/10.1017/S136898001700307X

37. Cozma Al, Sievenpiper JL, de Souza RJ, et al. Effect of fructose on glycemic control in diabetes: A systematic review and meta-analysis of controlled feeding trials. Diab Care. 2012;35(7):1611-1620. https://doi.org/10.2337/dc12-0073

38. Wang $D$, Sievenpiper JL, de Souza R, et al. Effect of fructose on postprandial triglycerides: A systematic review and meta-analysis of controlled feeding trials. Atherosclerosis. 2014;232(1):125-133. https://doi.org/10.1016/j.atherosclerosis. 2013.10.019

39. Chiu S, Sievenpiper JL, de Souza RJ, et al. Effect of fructose on markers of nonalcoholic fatty liver disease (NAFLD): A systematic review and meta-analysis of controlled studies. Eur J Clin Nutr. 2014;68(4):416-423. https://doi.org/10.1038/ controlled stud

40. Satija A, Yu E, Willett WC, Hu FB. Understanding nutritional epidemiology and its role in policy. Adv Nutr. 2015;6(1):5-18. https://doi.org/10.3945/an.114.007492

41. Lesser LI, Ebbeling CB, Goozner M. Relationship between funding source and conclusion among nutrition-related scientific articles. PLoS Med. 2007;4(1):e5. https://doi.org/10.1371/journal.pmed.0040005

42. Barclay AW, Brand-Miller J. The Australian paradox: A substantial decline in sugars intake over the same timeframe that overweight and obesity have increased. Nutrients. 2011;3(8):491-504. https://doi.org/10.3390/nu3080734

43. Martin P. Australian paradox author admits sugar data might be flawed [homepage on the Internet]. Sydney Morning Herald. 2014 [cited 2018 Apr]. Available from https://www.smh.com.au/healthcare/australian-paradox-author-admits-sugardata-might-be-flawed-20140209-329h1.html

44. Robertson R. Australian Paradox. n.p.; 2018.

45. Malhotra A, Noakes T, Phinney S. It is time to bust the myth of physical inactivity and obesity: You cannot outrun a bad diet. Br J Sports Med. 2015;49(15):967-968. https://doi.org/10.1136/bjsports-2015-094911

46. Aaron DG, Siegel MB. Supporting public health to deflect Coke and Pepsi sponsorship of national health organizations by two major soda companies. Am Prev Med. 2017;52:20-30. https://doi.org/10.1016/j.amepre.2016.08.010

47. Waters R. Trump's pick to head CDC partnered with Coke, boosting agency's longstanding ties to soda giant [homepage on the Internet]. Forbes. 2017 [cited 2018 Apr]. Available from: https://www.forbes.com/sites/robwaters/2017/07/10/ trumps-pick-to-head-cdc-partnered-with-coke-boosting-agencys-longstandingties-to-soda-giant/\#3bb6da2657b5

48. O'Connor A. Coca-Cola funds scientists who shift blame for obesity away from bad diets. [homepage on the Internet]. The New York Times. 2015 [cited 2018 Apr] Available from: https://well.blogs.nytimes.com/2015/08/09/coca-cola-fundsscientists-who-shift-blame-for-obesity-away-from-bad-diets/
49. Waters R. The Coca-Cola Network: Soda giant mines connections with officials and scientists to wield influence [homepage on the Internet]. Forbes. 2017 [cited 2018 Apr]. Available from: https://www.forbes.com/sites/robwaters/2017/07/11/theApr]. Available from: https://www.forbes.com/sites/robwaters/2017/07/11/thewield-influence/\#219936f2185c

50. Simon M. And now a word from our sponsors: Are America's nutrition professionals in the pocket of Big Food? [homepage on the Internet]. Eat Drink Politics. 2013 [cited $2018 \mathrm{Apr}$. Available from: http://www.eatdrinkpolitics.com/wp-content/ uploads/AND_Corporate_Sponsorship_Report.pdf

51. Action BM. Nestle boycott [homepage on the Internet]. 2018 [cited 2018 Apr]. Available from: http://www.babymilkaction.org/nestlefree

52. Pomeranz JL. The bittersweet truth about sugar labeling regulations: They are achievable and overdue. Am J Public Health. 2012;102(7):e14-e20. https://doi. org/10.2105/AJPH.2012.300732

53. Jones NR, Conklin Al, Suhrcke M, Monsivais P. The growing price gap between more and less healthy foods: Analysis of a novel longitudinal UK dataset. PLoS One. 2014;9(10):e109343. https://doi.org/10.1371/journal.pone.0109343

54. Cubanski J, Neuman T. The facts on medicare spending and financing [homepage on the Internet]. Henry J Kaiser Family Foundation. 2017 [cited 2018 Apr]. Available from: https://www.kff.org/medicare/issue-brief/the-facts-on-medicare-spendingand-financing/

55. Institute CSR Sugar: Consumption at a crossroads [homepage on the Internet] 2013 [cited 2018 Apr]. Available at: http://wphna.org/wp-content/ uploads/2014/01/13-09_Credit_Suisse_Sugar_crossroads.pdf

56. Collaboration. GBoMRFfCD Cardiovascular disease, chronic kidney disease, and diabetes mortality burden of cardiometabolic risk factors from 1980 to 2010: A comparative risk assessment. Lancet Diabetes Endocrinol. 2014;2(8):634-647. https://doi.org/10.1016/S2213-8587(14)70102-0

57. Triggle N. NHS ranked 'number one' health system [homepage on the Internet] BBC News. 2017 [cited 2018 Apr]. Available from: http://www.bbc.com/news/ health-40608253

58. Federal Trade Commission. In the matter of Sugar Information, Inc., et al. FTC Decisions [homepage on the Internet]. 1972 [cited 2018 Apr]; pp. 711-724. Available from: https://www.ftc.gov/sites/default/files/documents/commission decision_volumes/volume-81/ftc volume decision_81_july_-_december 1972pages 678-778.pdf\#page $=34$

59. Commission FT. Advertising to kids and the FTC: A regulatory retrospective that advises the present [homepage on the Internet]. 2002 [cited 2018 Apr]. Available from: https://www.ftc.gov/sites/default/files/documents/public statements/advertising-kids-and-ftc-regulatory-retrospective-advises-present/ 040802adstokids.pdf

60. Ahmed A, Richtel M, Jacobs A. In NAFTA talks, US tries to limit junk food warning labels [homepage on the Internet]. The New York Times. 2018 [cited 2018 Apr] Available from: https://www.nytimes.com/2018/03/20/world/americas/naftafood-labels-obesity.html

61. Barrington M. Guest Choice Network - Privileged and confidential [homepage on the Internet]. PR Watch. 1996 [cited 2018 Apr]. Available from: https://web.archive. org/web/20070927191427/http://www.prwatch.org/documents/berman/ pm300k.pdf

62. Lipton E. Hard-nosed advice from veteran lobbyist: 'Win ugly or lose pretty'. Richard Berman energy industry talk secretly taped [homepage on the Internet]. The New York Times. 2014 [cited 2018 Apr]. Available from: https://www.nytimes. com/2014/10/31/us/politics/pr-executives-western-energy-alliance-speechcom $/ 2014 / 10$

63. Transparify. How transparent are think tanks about who funds them 2016? [homepage on the Internet]. 2016 [cited 2018 Apr]. Available from: https:// static1.squarespace.com/static/52e1f399e4b06a94c0cdaa41/t/5773022 de6f 2e1ecf70b26d1/1467154992324/Transparify+2016+Think+Tanks+Report.pdf

64. University of California San Francisco Library. American friends of the IEA [homepage on the Internet]. Truth Tobacco Industry Documents. 2018 [cited 2018 Apr]. Available from: https://www.industrydocumentslibrary.ucsf.edu/tobacco/ docs/\#id=ttjy0045

65. Snowdon C. Decline in physical activity to blame for rise in obesity [homepage on the Internet]. Institute for Economic Affairs. 2016 [cited 2018 Apr]. Available from: https://iea.org.uk/in-the-media/media-coverage/decline-in-physical-activity-toblame-for-rise-in-obesity

66. Diehr P, Derleth A, Cai L, Newman AB. The effect of different public health interventions on longevity, morbidity, and years of healthy life. BMC Public Health 2007;7:52. https://doi.org/10.1186/1471-2458-7-52

67. Tobacco tactics [homepage on the Internet]. Christopher Snowdon. [cited 2018 Apr] Available from: http://www.tobaccotactics.org/index.php/Christopher_Snowdon

68. Brownell KD, Kersh R, Ludwig DS, et al. Personal responsibility and obesity: A constructive approach to a controversial issue. Health Aff. 2010;29(3):379-387. https://doi.org/10.1377/hlthaff.2009.0739 